\title{
LOOP LENGTH MODEL OF FILLET STRUCTURE
}

\author{
Olena Kyzymchuk, Inna Ermolenko \\ Kyiv National University of Technology and Design /2, Nemirovich-Danchenko str. \\ Kyiv 01011. Ukraine
}

It is well known, that unit element of a knit structure is a loop. The loop configuration that is obtained in the knit depends on both qualitative and quantitative factors, the most important of which is the loop length. The loop configuration in the knit fabric of same interlooping from yarns of the same composition and same linear density is different and varies depending on the loop length. Thus, it is necessary to have a geometrical model of knitted loop configuration.

Few studies have been undertaken on the geometry of warp-knitted structures. The first geometrical model for warp knitted structures (Allison, 1958) was quite simple model, in which the unit stitch shape consisted of semi-circle plus two converging straight legs and straight underlap section. Second geometrical model of loop configuration was presented and improved by Grosberg for two bar warp knitted fabric (Grosberg, 1964). It is based on physical configuration of the yarn. He assumed that the loop and underlap are effectively isolated from each other by friction, the root end of the loop lays at the widest section of the previous loop and the underlap is a part of a circle. Other geometrical model, in which loop was described by the sum of lines, parts of circles or ellipses, was proposed by Dalidovich for single bar warp knit structure (Dalidovich, 1970). He assumed that yarn has same diameter, deformation property and a circle in the section at each part of loop. These models are flat mostly, but at real knit structure loops are unfolded, bent and curved. So it is logical to represent them as spatial curves in 3D model.

General 3D loop and underlap models for basic two-bar full-set warp knitted structures were developed by CAD program to obtain a three dimensional loop model that is suitable for visual computer representation of warp-knitted structures (Goktepe, 2002). A 3D straight line model also should be used to predict the behavior of two-guide-bar 
warp knit fabric (Dabiryan, 2011). The accurate calculation of the run-in values verifies the proposed 3D loop models. But all these models were developed for full-set basic warp knit structures.

Also, it is well known, that net warp knitted fabric can be produced by using half-set two-guide-bar fillet interlooping. However, few loop configurations differ by size, form and shape in such structure (Ermolenko, 2011). In previous study (Ermolenko, 2013) presented 3D loop models of net knit structure with hexagonal cell which is formed by alternation of tricot and atlas courses at repeat. The aim of this research is to develop our loop model for net knit structure with hexagonal cell which is formed by alternation of tricot and chain courses. Vertical ribs of such net structure consist of tricot closed loops of identical configuration while diagonal ribs consist of tricot and chain loops of different type, shape and form. In this study each loop is presented as sum of planar and spatial lines, the length of which can be easily calculated by the well-known formulas. Numerical dependences for loop length calculation are determined as a result of mathematical transformations.

To verify the suggested model few variants of fillet warp knit structures were produced from polyester yarn. The investigation showed that theoretical average loop length of repeat corresponds to experimental value. It is concluded that the model can predict geometrical properties of half set two guide bar warp knitted fabric.

Keywords: Geometrical model, warp knitting, fillet interlooping, loop length

\section{REFERENCES}

ALLISON, G.L. Warp-knitting calculation made easy. Skinner's Silk Rayon Record, 1958, vol. 32, pp 281-283.

DABIRYAN, H., Jeddi A.A. Analysis of warp knitted fabric structure. Part 1: a 3D straight model for warp knitted fabrics. Journal of the Textile Institute, 2011, vol. 102, no. 12, pp 1065-1074.

DALIDOVICH, A.S. Basics of knitting technology. Moscow: Legkaya Industriya, 1970, 296 p. In Russian 
ERMOLENKO, I., KYZYMCHUK, O. The creation of hexagonal cells in fillet knitted fabric. Bulletin of Kyiv National University of Technologies and design, 2011, no 1, pp 97-100. In Ukrainian

ERMOLENKO, I., KYZYMCHUK, O. Loop length of the fillet interlooping. Izvestiya VUZov. Technology of Light Industry, 2013, no 3, pp 3-7. In Russian. GOKTEPE, O , HARLOCK, S.C. A 3D loop model for visual simulation of warp-knitted structures. Journal of the Textile Institute, 2002, vol. 93, part 1, no. 1, pp 11-28.

GROSBERG, P. The geometrical properties of simple warp-knit fabric. Journal of Textile Institute, 1964, vol. 55, pp T18-T30.

Corresponding address:

Olena KYZYMCHUK,

$\mathrm{PhD}$, Docent

Department of Knitting Technology

Faculty of Technologies, Service and Fashion

Kyiv National University of Technology and Design

2 Nemirovich-Danchenko str.

Kyiv, 01011 Ukraine

e-mail: kyzymchuk_knutd@ukr.net, kyzymchuk.o@knutd.com.ua 